\title{
Manajemen Diversity dan Kesetaraan dalam Lembaga Pendidikan Islam: Suatu Analisis Realitas Sosial
}

\section{Ivan Riyadi}

Universitas Islam Negeri Raden Fatah Palembang, Indonesia

ivanriyadi uin@radenfatah.ac.id

\begin{abstract}
This article is written based on consideration of the reality of students as a diversity and equality community that is unique to discuss, often also occurs in Islamic educational institutions in diversity that can be solved by diversity management and equality that have a spirit of togetherness and vision of unity. To get a complete picture in this article, a qualitative approach to the design of literature research is used. The results show that diversity management and equality can be a solution to create peace in the school's scope of diversity. The relationship of educational institutions to the community is an effort that can be felt in creating harmony among ethnic groups.
\end{abstract}

Keywords; Diversity, management, Islamic Education, Equality.

\begin{abstract}
Abstrak
Artikel ini ditulis berdasarkan pertimbangan pada realitas peserta didik sebagai masyarakat yang diversity dan kesetaraan yang unik untuk dibahas, kerap juga terjadi pada lembaga pendidkan Islam dalam keragaman yang dapat diselesaikan dengan manajemen diversity dan kesetaraan yang memiliki semangat kebersamaan dan visi kesatuanl. Untuk mendapatkan gambaran yang utuh dalam artikel ini, maka digunakan pendekatan kualitatif dengan desain penelitian literatur. Hasil penelitian menujukkan bahwa manajemen diversity dan kesetaraan bisa menjadi solusi untuk menciptakan kedamaian diruang lingkup sekolah dalam keragaman. Hubungan lembaga pendidikan terhadap masyarakat merupakan usaha yang dapat dirasakan manfaatnya dalam menciptakan kerukunan antar etnis kelompok.
\end{abstract}

Kata Kunci: Diversity, Manajemen, Pendidikan Islam, Kesetaraan.

Accepted: 21-10-2019; published: 30-12-2019

Citation: Wahyu Kurniawan, 'Sumber Kejahatan dalam Perspektif Psikologi Islam', Mawa'izh: Jurnal Dakwah dan Pengembangan Sosial Kemanusiaan, vol. 10, no. 2 (2019), pp. 231-247. 


\section{Pendahuluan}

Tdonesia merupakan negara kepulauan yang memiliki banyak keragaman budaya, suku, bahasa, adat dan keyakinan. Nusantara terdiri secara garis besar yaitu struktur kesukuan, tingkat pendidikan, letak wilayah daerah. Keragaman tersebut dalam dunia pendidikan merupakan hal positif untuk menjadikan kekayaan khasah disiplin keilmuan. Keragaman di Nusantara terbingkai dalam Pancasila membentuk kerukunan, kedamaian, memfasilitasi suatu perbedaan, kesenjangan walaupun berbeda tetap satu.

Namun tanpa menafikan fenomena konflik yang terjadi pada masyarakat mencederai makna Pancasila. Fenomena konflik mengganggu kerukunan masyarakat yang hidup damai sesuai dengan citi-cita leluhur. Keragaman dalam masyarakat sekolah bersifat multidimensi, terdiri dari berbagai suku, strata pendidikan orang tua, ekonomi, profesi orang tua, keluarga yang lengkap, keluarga brokenhome.

Keragaman dan keseteraan peserta didik dalam Lembaga pendidikan yang dikelola dengan baik mampu merumuskan kebudayaan Indonesia. Lembaga pendidikan Islam mengambil peran penting dalam merumuskan kebudayaan nasional. Kebudayaan nasional dapat dirumuskan dengan suatu sistem dan gagasan perlambang yang menjadikan bagian identitas dari masyarakat Indonsia. Peserta didik merupakan warna negara Indonsia yang mencerminkan identitas bangsa Indonesia untuk saling mengenali dalam kesetaraan dengan tujuan untuk memperkuan solidaritas saudara sesama bangsa dan budaya.

Keragaman dan kesetaraan peserta didik yang tersusun dalam tradisi dan budayanya membuktikan bahwa Indoseia adalah negara yang kuat dan negara yang berpeluang dalam potensi kemajuan. Akan tetapi kekayaan Indonesia yang tidak bisa dikelola dengan baik akan menimbulkan perbedaan rasa, rasa yang tidak adil akan menimbulkan konflik di masyarakat. Konflik terjadi akan menimbulkan dan mengancam sendi-sendi nasionalisme dan rasa persatuan.

Peserta didik merupakan bagian dari unsur pembentuk sistem sosial masyarakat sekolah yang beragama dan kesetaraan. Kelompok-kelompok etnik dalam lingkup sekolah memiliki kebudayaan dalam batas-batas sosial budaya yang menandai identitas dan eksistensi budaya masyarakat sekolah. Kebudayaan dalam masyarakat yang terjadi 
merupakan bagian dari atribut atau dengan kata lain ciri-ciri budaya yang menandai identitas.

Diversity atau keragaman dalam konteks kesataraan pada Lembaga pendidikan sebagai contoh peserta didik berasal dari orang jawa maka mereka disebut suatu kelompok etnik dan memang secara budaya orang jawa berbeda sama orang Madura. Dalam contoh lain peserta didik berasal dari orang jawa timur, tentunya orang Jember berbeda dengan orang Surabaya karena berbeda secara kultural, walaupun orang Jember dan Surabaya sama-sama orang yang berasal dari Jawa Timur. Dengan perbedaan ini maka orang jawa dan madura, orang jember dan Surabaya merupakan berbeda secara kultural sehingga disebut sebagai kelompok etnik.

Diversity dalam kesuku bangsaan akan selalu hadir dalam konteks masyarakat yang bermacam kultural dan kelompok etnik. lembaga pendidikan harus memahami dan mengerti terhadap realitas yang terjadi pada masyarakat Indonesia bahwa perbedaan dan kemajemukan yang ada di Nusantara merupakan suatu keniscayaan keberadaannya karena Indonesia yang kaya akan adanya suku bangsa, etnis dan budaya. Pada proses pendidikan yang terjadi pada Lembaga pendidikan merupakan bagian dari individu peserta didik dalam kelompok etnik akan menggunakan atributatribur sosial budaya seperti berbahasa, gestur berbicara yang mewakili dari kelompok tertentu. Sehingga Lembaga pendidikan harus memahami dengan adanya perbedaan tersebut.

Sebagai contoh, pengaruh daerah sub tropis terhadap pola kerja manusia akan berbeda dengan daerah tropis. Pada daerah sub tropis ada musim dimana manusia kurang atau tidak dapat bekerja secara penuh, terutama pada musim dingin, sehingga keadaan ini memaksa manusia daerah sub tropis untuk mempersiapkan cadangan makanan untuk musim dingin. Demikian pula masyarakat di daerah gersang akan terpaksa bekerja lebih keras untuk mempertahankan hidupnya dibandingkan dengan daerah subur. ${ }^{1}$

Konsep manajemen dalam pendidikan digunakan sebagai pendekatan dalam pengelolaan mutu pendidikan. Peran pendidikan pada hakikatnya ditafsirkan sebagai

\footnotetext{
${ }^{1}$ Harun Nasution, Islam Ditinjau dari Berbagai Aspeknya (Penerbit Universitas Indonesia, 1985).
} 
perubahan sosial dan pusat peradaban. ${ }^{2}$ Hasil penelitian Heyneman dalam Supriadi ${ }^{34}$ mengemukakan bahwa, kemajuan sebuah bangsa dan perubahan sosial sangat ditentukan oleh pelaksanaan mutu pendidikan pada konteks tersebut pendidikan menjadi yang tempat strategis dan untuk mengantarkan cita-cita ideal dimaksud, maka dibutuhkan sistem manajemken strategis dalam pengelolaan pendidikan.

Pendidikan dalam konsep pengembangan masyarakat merupakan dinamisasi dalam pengembangan manusia yang beradab. Pendidikan tidak hanya terbatas berperan pada pengalihan ilmu pengetahuan (Transfer of knowledge) saja, namun juga berfungsi mengembangkan kemampuan dan membentuk watak serta peradaban bangsa yang bermartabat dalam rangka mencerdaskan kehidupan bangsa, bertujuan untuk berkembangnya potensi mahasiswa agar menjadi manusia yang beriman dan bertaqwa kepada Tuhan Yang Maha Esa, berakhlak mulia, sehat, berilmu, cakap, kreatif, mandiri, dan menjadi warga negara yang demokratis serta bertanggung jawab. ${ }^{5}$ Dari fungsi dan tujuan pendidikan ini diharapkan manusia Indonesia adalah manusia yang berimbang antara segi kognitif, afektif, dan psikomotor, dan dalam pencapaian tujuan pendidikan nasional.

Adapun kegelisahan akademik dalam penelitian ini adalah terjadinya konflik dalam sendi-sendi masyarakat yang belum terselesaikan dan harus mendapatkan jalan keluar dan solusinya yang dimulai pada manajemen Lembaga pendidikan Islam. dari fokus permasalahan tersebut, yaitu 1) Apa saja keragaman dan kesetaraan lembaga Pendidikan Islam dan 2) Bagaimana manajemen diversity dan kesetaraan peda peserta didik. Dari rumusan masalah tersebut, maka tujuan dari penelitian ini adalah merumuskan tentang manajemen diversity dan kesetaraan peserta didik yang memberikan kontribusi terhadap lembaga pendidikan Islam. Peran manejemen diversity pendidikan dan memberikan rumusan hubungan signifikan diversity dan kesetaraan dalam dunia pendidikan. Pendidikan yang ada pada dataran empirik akan

2 Karel A. Steenbrink, Pesantren, Madrasah, Sekolah: Pendidikan Islam Dalam Kurun Moderen (Lembaga Penelitian, Pendidikan dan Penerangan Ekonomi dan Sosial, 1986).

${ }^{3}$ Supriadi, D. Mengangkat Citra dan Martabat Guru. Jakarta: (Adicita Karya Nusantara, 1999).

${ }^{5}$ Sri Winarsih, 'Kebijakan dan Implementasi Manajemen Pendidikan Tinggi dalam Meningkatkan Mutu Pendidikan', Cendekia: Jurnal Kependidikan Dan Kemasyarakatan 15, no. 2 (24 June 2017), p. 51-66, https://doi.org/10.21154/cendekia.v15i2.1005. 
dapat sebagai salah satu upaya memahami dan melihat wujud prilaku peserta didik yang tumbuh dan berkembang dalam masyarakat.

\section{Metode Penelitan}

Artikel ini menggunakan metode studi literatur (literature study), pencarian hasil riset ataupun sebuat teori yang berkaitan dengan pembahasan dalam artikel yang sedang dikaji. Sehingga teori-teori dan hasil penelitian tentang manajemen pendidikan Islam, teori masyarakat majemuk, interaksi antropologi, agama dan sosial.

Adapun referensi diperoleh melalui laporan penelitian khususnya yang sudah dipublikasikan, jurnal nasional ataupun artikel internasional, buku, adapun prosedur dalam penelitian literatur tersebut melalui tiga tahapan yaitu; pertama pengumpulan, keduaadalisis data, ketiga penarikan kesimpulan. Tanpa ingin mengklaim sebagai kemutlakan kebenaran hasil kajian, kita juga dituntut berupaya menemukan rumusan tentang definisi agama, dari pendekatan kebahasaan hingga tinjauan istilah, secara substansial maupun fungsional.

\section{Kajian Literatur}

Dalam jurnal Jenny Maria Fatimah dengan judul Komunikasi Keluarga Meningkatkan Akses Pendidikan Bagi Kesetaraan Anak Perepuan Dalam Lingkaran Kemiskinan. Kesetaraan melalui komunikasi tak terlepas dari peranan dominan orang tua dan komunikasi sehingga meningkatkan pendidikan untuk anak. ${ }^{6}$ Sebagaimana Setudi Purwanto menemukan bahwa budaya yang kuat dibangun melalui beberapa aspek, antara lain; komitmen (commitment), kemampuan (kopetence), perpaduan (cohesion) dan konsistensi (konsistency). Kondisi tersebut harus dapat dilaksanakan secara konsisten, sebagaimana yang telah disepakati bersama dan merupakan satu kesatuan yang tidak dapat dipisah-pisahkan. ${ }^{7}$

Dalam jurnal Abd Somad dengan judul Selayang Pandang tentang Antropologi Pendidikan. Masyarakat (society) dan kebudayaan (culture) saling bergantung satu sama lain. Masyarakat tidak mungkin merupakan satu kesatuan fungsional tanpa kebudayaan, demikian pula sebaliknya. Individu-individu hanya sebagai medium ekspresi

\footnotetext{
${ }^{6}$ Jenny Maria Faimah, 'Komunikasi Keluarga Meningkatkan Akses Pendidikan Bagi Kesetaraan Anak Perepuan Dalam Lingkaran Kemiskinan', Jurnal Mimbar , Makassar, 2014, p. 199.

7 Iwan Purwanto, 'Manajemen Strategi', (Bandung: Yrama Widya, 2008).
} 
kebudayaan dan melangsungkannya dengan pendidikan terhadap generasi berikutnya. Implementasi. ${ }^{8}$

Kemudian jurnal yang ditulis oleh M. Dimyati Huda Eneng Fauziah dengan judul Pendekatan Antropologis dalam Studi Islam. Pendekatan antropologis dalam memahami agama dapat diartikan sebagai salah satu upaya memahami agama dengan cara melihat wujud praktek keagamaan yang tumbuh dan berkembang dalam masyarakat. Antropologi adalah suatu disiplin ilmu yang membawa pengertian world view yang bergantung kepada perspektif saintifik, aliran falsafah atau kepercayaan agama seseorang. Dengan world view inilah seseorang dapat memahami diri dan dunianya. Dengan mempelajari antropologi, kita bisa menyadari keragaman budaya umat manusia dan pengaruh dalam pendidikan. ${ }^{9}$ Pada hakekatnya setiap kebudayaan adalah unik atau tidak sama dengan kebudayaan yang lain, bahwa setiap masyarakat mempunyai kebudayaan masing-masing dan bahwa setiap agama untuk dapat berpijak di bumi hidup dan berkembang serta lestari dalam masyarakat haruslah menjadi pedoman yang diyakini kebenarannya bagi kehidupan suatu masyarakat. ${ }^{10}$ itu harus sanggup mengubah masyarakat untuk dibawa ke arah cita-cita. Untuk dapat hidup dan berkembang serta lestari dalam masyarakat, agama harus menjadi kebudayaan bagi masyarakat. Karena setiap masyarakat memiliki kebudayaan yang digunakan sebagai pedoman untuk mengelola atau manajemen pendidikan dalam lingkungan hidup, kebutuhan sosial. ${ }^{11}$

Secara garis besar Jurusan Manajemen Pendidikan Islam berkonsentrasi pada manajemen pendidikan Islam, supervisi pendidikan Islam, pemikiran pendidikan Islam serta bimbingan konseling pendidikan Islam. Sedangkan Jurusan PAI konsentrasi utamanya pada profesi pengajar atau Keguruan. Salah satu tujuan utama Jurusan MPI adalah menghasilkan praktisi kependidikan Islam yang profesional dan memiliki komitmen terhadap keunggulan kompetensi, kompetitif, dan inovatif. Secara spesifik

8 Abd Shomad, 'Selayang Pandang Tentang Antropologi Pendidikan Islam', Jurnal Pendidikan Agama Islam 1, no. 1 (2004).

${ }^{9}$ M. Dimyati Huda, 'Pendekatan Antropologis Dalam Studi Islam', Didaktika Religia 4, no. 2 (2016): p. $139-62$. 2001).

10 Parsudi Suparlan, 'Pendidikan Agama Islam: Tinjauan Disiplin Antropologi', (Bandung: Nuansa,

11 Harun Nasution et al., Tradisi Baru Penelitian Agama Islam: Tinjauan Antar disiplin Ilmu (Diterbitkan atas kerja sama Pusjarlit dengan Nuansa, 1998). 
orientasi profesi alumni MPI adalah menjadi; 1) Manajer LembagaPendidikan Islam (LPI), 2) Konsultan manajemen Lembaga Pendidikan Islam, 3) Praktisi lembaga pendidikan Islam (tenaga kependidikan Islam), 4) Peneliti di bidang kependidikan Islam, 5) Tenaga edukatif kependidikan Islam. ${ }^{12}$

\section{Hasil dan Pembahasan}

Manajemen diversity dan kesetaraan pada Lembaga pendidikan Islam yang harus disadari oleh orang Indonesia bahwa pelajar yang terdiri dari golongan dominan dan minoritas. Dalam hal ini dapat dilihat sebagaiman fenomena yang terjadi dalam masyarakat melalui interaksi antar masyarakat di lingkungan sekolah. Peserta didik merupakan bagian dari masyarakat luas yang memiliki keragaman kelompok etnis, adat istiadat, tradisi, bahasa, kesenian, kesamaan leluhur, asal usul daerah yang menjadi pusat perhatian dalam melaksanakan demokrasi. Manajemen diversity pada peserta didik dapat dilakukan dengan cara menerapkan ide-ide pluralisme dan multikultural dalam lembaga pendidikan Islam.

Multikulturalisme merupakan paham yang terdiri dari keragaman. Dalam keragaman dengan cara menyikapi dengan saling hormat menghormati, Saling mengerti, mengutamakan kebersamaan dalam bingkai perdamaian dan terhindar dari konflik yang berkepanjangan. ${ }^{13}$ Maka dalam hal ini manajemen diversity diawali di lembaga pendidikan yang menciptakan peserta didik yang memiliki sikap keragaman, memperhatikan kebersamaan, atau hanya memperhatikan kesamaan.

Salah inti dari pendidikan multikultural adalah pengakuan terhadap harkat manusia dan hak asasi manusia. ${ }^{14}$ Dalam lembaga pendidikan harus menerapkan kebudayaan belajar yang saling menjaga perdamaian, toleransi, dan mengutamakan kesamaan baik kesamaan sebagai umat Islam maupun kesamaan sebagai makhluk ciptaan Tuhan yang hadir dalam ruang lingkup kesamaan tanah air.

12 M. Misbah, 'Reorientasi Jurusan Manajemen Pendidikan Islam (MPI) Antara Tenaga Kependidikan dan Tenaga Pendidik', Cendekia: Jurnal Kependidikan dan Kemasyarakatan 16, no. 1 (30 July 2018): 83-101, https://doi.org/10.21154/cendekia.v16i1.1178.

13 Nganun Naim dan Achmad Sauqi. Pendidikan Multicultural Konsep dan Aplikasi, cet-ke 3(Yogyakarta: Ar-Ruzz Media, 2011). p.125.

${ }_{14}$ H.A.R Kekuasaan dan Pendidikan Suatu Tinjauan dan Perpektif Studi Kultural, Magelang: Indonesia, 2003), p. 171. 
Peserta didik merupakan makhluk sosial dan berbudaya yang dilatarbelakangi oleh nilai-nilai pada diri peserta didik, karena nilai-nilai yang tertanam pada peserta didik merupakan dari bagian nilai-nilai kemanusiaan sendiri. Nilai-nilai kemanusiaan berupa moralitas yang dapat dipahami dari sudut pandang dari manapun. Jika dilihat dari sudur pandang fisiologis maka manusia mirip hewan, hewan mempunyai kepala telinga, kaki, maka secara fisik juga manusia mempunyai kesamaan yang dimiliki oleh hewan. Maka dalam hal ini yang menjadi informasi pengetahuan adalah manusia memiliki akal untuk berfikir tentang kemarin, hari ini dan esok hari.

Manajemen diversity dan kesetaraan mengandung nilai-nilai kemanusiaan yang dapat mengembalikan peserta didik sebagai manusia kepada fitrahnya. Fitrah seseorang peserta didik memiliki sisi baik dan sisi buruk, sisi kekurangan dan sisi anugrah kepintaran. Namun disisi lain manusia mempunyai fitrah kesempurnaan berusaha untuk menjadi insan kamil. Cara peserta didik untuk menyempurnakan diri yaitu dengan cara belajar dan mencari informasi terkait dengan hal-hal yang belum diketahui atau permasalahan yang belum terpecahkan. Dari pengetahuan tersebut menentukan proses penyempurnaan diri.

Proses pembudayaan di lembaga pendidikan tersebut merupakan suatu cara untuk mencapai penyempurnaan diri. Peserta didik sebagai manusia yang hadir di muka bumi ini dalam keadaan tidak sempurna berperan. Maka ada kebudayaan yang harus diketahui oleh peserta didik yaitu kebudayaan yang dekat dengan syariat merupakan sesuatu yang baik disertakan sebagai kebudayaan yang menempel saja dianggap sebagi kearifan lokal. Namun demikian ada juga kebudayaan yang sama sekali tidak ada hubungannya dengan Islam.

Keberagaman dalam kebudayaan merupakan fasilitas alam yang perlu dikaji dan dikembangkan dalam kesetaraan. Ada etika yang perlu dipahami oleh peserta didik untuk mempelajari dari makna keberagaman tersebut. Pada saat peserta didik mengetahui terhadap objektif identitas maka dalam proses terjadinya perubahan tersebut yang menjadi sebuat teori pembelajaran terbagi beberapa item pembahasan. Mulai dari media pembelajaran, materi ajar, metode, dan Teknik dalam pembelajaran.

Manajemen diversity dan kesetaraan pada lembaga pendidikan Islam dapat dikelola dengan cara membina hubungan antar peserta didik. Hubungan tersebut dapat 
dikembangkan dan dilestarikan. Maka hubungan antar peserta didik tersebut dapat dibina dengan cara memahami antar kebiasaan dan budaya kebiasaan yang menjadi norma pada setiap lingkungan peserta didik. Kebiasaan tersebut terjadi dengan sikap yang selaras dengan nilai-nilai norma agama. Sehingga terjadi sikap saling menghargai dan saling menghormati antar kelompok etnis peserta didik. Untuk meminimalisir terjadinya pergeseran dan persoalan pada dunia pendidikan yang berkutik pada masalah yang bukan pada substantif yang berpusat pada peserta didik.

Persoalan Pendidikan jangan hanya dianggap melulu persoalan pedagogis, didaktis, metodis dan tidak menjadi masalah kebijakan sosial, sehingga pendidikan tidak lagi menjadi kebutuhan bersama. Untuk itu perlu analisa empiris tentang tugas pendidikan dalam konteks kehidupan masyarakat". ${ }^{15}$ Dalam konteks kehidupan masyakat sekolah pada lembaga pendidikan Islam bahwa perbedaan dan kesetaraan peserta didik yang harus ditarik kedalam konteks kebudayaan masyarakat Indonesia yang kaya akan budaya nasional yan bersifat unik. Maka dalam lembaga pendidikan harus selalu mengikuti perkembangan pada isu-isu diversity yang berkembang untuk dilakukan perbandingan diversity dan kesetaraan baru yang bersifat tentatif.

Lembaga pendidikan Islam selalu berproses dalam diversity dan kesetaraan dalam sejarah dan budaya tidak tercapai tujuan nasional tanpa memahami hakikat pada peserta didik. Karena sesungguhnya realitas keragaman adalah realitas kemanusiaan sendiri dalam dunia pendidikan. Konteks diversity terletak pada interpretasi dan prilaku sosial peserta didik oleh karena itu menghargai sangat diperlukan untuk menjaga kerukunan antar etnis, keturunan, dan kebiasaan. Sikap menghargai sebagai alat untuk mengerti realitas peserta didik di lingkungan sekolah yang merupakan miniatur dari diversity masyarakat Indonesia.

Diversity dalam konteks perbedaan budaya yang tercermin dalam perasaan peserta didik merupakan suatu wawasan yang harus dipahami oleh banyak peserta didik lainnya. Karena bagi mereka yang merasakan hasil interaksi terhadap kemajemukan tentunya berbeda dengan yang tidak merasakan suatu simbol dari keragaman tersebut. Demikian pula dalam sudut pandang psikologi memahami keragaman berbeda dengan sudut pandang ekonomi, politik dan agama.

15 Koentjaraningrat, Pengantar Ilmu Antropologi (Penerbit PT Rineka Cipta, 1990). 
Sudut pandang agama adalah sebagai persoalan universal manusia. Bagi J.G.Frazzer, seperti penuturan Bahtiar, agama didefinisikan dengan penyembahan kepada kekuatan yang lebih agung dari pada manusia, yang dianggap mengatur dan menguasai jalannya alam semesta. ${ }^{16}$ Sementara, Mehdi Ha'iri Yazdi berpendapat bahwa agama adalah kepercayaan kepada yang mutlak atau kepada kehendak mutlak sebagai kepedulian tertinggi. ${ }^{17}$ Keragaman dalam sudut pandang agama merupakan sebuah keniscayaan yang hadir ditengah kehidupan manusia merupakan suatu perbedaan yang saling melengkapi dalam memenuhi kekurangan. Agama menganjurkan untuk selalu bekerjasama dalam kebaikan walaupun ditengah perbedaan.

Kesetaraan dalam perbedaan merupakan keniscayaan yang dirasakan sebagai suatu persamaan dalam suatu masyarakat sekolah yang bagian kecil suatu bangsa. Pendidikan Islam merupakan suatu tugas penting dalam menjalankan fungsi-fungsi negara untuk mewujudkan kedamaian. Usaha lembaga pendidikan Islam untuk menemukan nilai-nilai kebenaran dan kekuatan yang terkandung pada keragaman peserta didik. Kekuatan yang dihasilkan dalam dunia pendidikan akan membentuk sikap saling percaya dan saling mempunyai kesamaan dalam perbedaan.

Keragaman dalam kesetaraan pada lembaga pendidkan islam terdapat dua aspek yaitu manusia dan budaya. Pada dasarnya lembaga pendidikan Islam dihadirkan untuk membantu negara dalam menciptakan suatu kerukunan. Kedamaiaan dan kesetraan antar identitas. Sehingga mengarahkan kepada kehidupan bernegara yang berdaya saing sudah bergeser dari isu-isu perbedaan sosial. Dalam hal ini jelas bahwa persoalan keragaman dan kesetaraan mendapatkan pembahasan yang lebih secara empiris dalam dunia pendidikan. tanpa memahami keragaman peserta didik maka perkara pada pendidikan belum juga terselesaikan.

\section{Interaksi Diversity dan Kesetaraan peserta didik}

Interaksi dimulai ketika peserta didik sejak bayi. Bayi belajar berinteraksi terhadap lingkungan sekitar melalui komunikasi dengan manusia yang terjadi timbal

16 Amsal Bakhtiar, Filsafat Agama: Wisata Pemikiran dan Kepercayaan Manusia (RajaGrafindo Persada, 2007).

17 Mehdi Ha'iri Yazdi and Ilmu Hudhuri, 'Prinsip-Prinsip Epistemologi Dalam Filsafat Islam, Ter', Ahsin Mohammad (Andung: Mizan, 1996). 
balik. Dengan perkembangan dan pertumbuhan usia seseorang sering terjadi konflik dengan kelompok lainnya yang disebabkan oleh prilaku yang tidak sesuai dengan norma masyarakat. Sehingga perlu kesetaraan dalam keragaman yang dapat mengontrol dan mengarahkan peserta didik.

Pendidikan menjadi faslitas dan gerakan yang berpijak kepada keberadaan agama dalam kehidupan manusia dengan membedakan apa yang mereka sebut sebagai common sense dan 'religious atau mystical event. Di dalam bahasa Latin terdapat kata religi yang berasal dari kata relegere dan religare. Relegere dapat diartikan berhati-hati, dengan maksud harus berpijak pada sejumlah aturan yang ketat. Kata religi bagi bangsa Roma menunjuk pada sikap kehati-hatian terhadap yang Maha Kudus, yang diyakini bersifat suci dan terhormat. ${ }^{18}$ Kata relegere juga dapat diartikan mengumpulkan atau membaca, yang dimaksudkan adalah sejumlah aturan tentang cara pengabdian kepada Tuhan yang terkumpul dalam kitab suci yang harus dibaca. ${ }^{19}$ Maka dalam hal ini perbedaan dalam memahami definisi agama sendiri merupakan suatu tanda kaya akan sebuah keilmuan. Lembaga pendidikan merupakan tempat dalam menuntut ilmu dan mengembangkannya agar menjadi peserta didik yang lebih bijak.

Peserta didik dalam menuntut ilmu harus ditanamkan dengan pembudayaan yang lebilh memanusiakan dan menghormati peserta didik lainnya. Proses pembudayaan pada peserta didik diwali dengan cara hidup bersama. Kebersamaan dalam suatu sistem norma yang saling menghargai. Sehingga perbedaan dalam masyarakat dapat berjalan dengan tertib tanpa adanya konflik dan benturan antar kelompok. Peserta didik yang mengalami dalam menuntut jati diri ketika masih remaja.

Remaja aset generasi mendatang bangsa Indonesia. Keberadaannya harus benarbenar diperhatikan dengan baik dan diarahkan kepada masa depan yang gemilang. Remaja selaku peserta didik harus mendapatkan haknya memperoleh pendidikan yang benar yang mempu membentuk pribadinya yang sempurna. ${ }^{20}$ Remaja di usia anak sekolah merupakan masa-masa yang sangat rawan, labil dan mudah terpengaruh oleh

\footnotetext{
18Sidi Gazalba, Islam Dan Perubahan Sosiobudaya: Kajian Islam Tentang Perubahan Masyarakat (Pustaka Antara, 1983).

${ }^{19}$ Nasution, Islam Ditinjau Dari Berbagai Aspeknya.

${ }^{20}$ Fery Diantoro, 'Manajemen Peserta Didik Dalam Pembinaan Perilaku Keberagamaan', Cendekia: Jurnal Kependidikan Dan Kemasyarakatan 16, no. 2 (22 November 2018): 409-26, https://doi.org/10.21154/cendekia.v16i2.1207.
} 
kondisi dan situasi sekelilingnya. Terjadinya kenakalan remaja akibat pergaulan yang salah.

\section{—Internalisasi kesetaraan dalam Diversity Pada Lembaga Pendidikan}

Internalisasi kesetaraan dalam diversity bersifat terbuka yang menerima suatu terhadap nilai-nilai moral yang diciptakan oleh toko masyarakat atau adat yang menjadi warisan sosial. Warisan sosial merupakan isi kepribadian yang muncul dan diimplementasikan dalam kehidupan sehri-hari. Nilai-nilai moral yang hadir dan dijadikan pembudayaan dalam lembaga pendidikan dapat menterjemahkan tujuan dari pendidkan nasional yang diinternalisasikan.

Proses internalisasi berlangsung sepanjang masa pertumbuhan dan perkembangan peserta didik di tengah lingkungan sekolah. Dengan pengalamannya tersebut, seseorang memiliki pengetahuan dan nilai-nilai ideal atau sistem nilai dan dinyatakan dalam perilaku. Sistem nilai tersebut dapat bersumber dari unsur-unsur kebudayaan, yang menurut Koentjaraningrat meliputi tujuh unsur, yakni: bahasa, sistem pengetahuan, organisasi sosial, sistem peralatan hidup dan teknologi, sistem mata pencaharian hidup, sistem agama.

Ilmu yang mempelajari manusia, menjadi sangat penting untuk memahami agama. Istilah agama dipahami sebagai sebuah sistem aturan tetap dan mengikat karena diyakini merupakan jalan hidup menuju suatu tujuan. ${ }^{21}$ Maka dalam hal ini mempelajari tentang manusia dan segala perilaku mereka untuk dapat memahami perbedaan kebudayaan manusia. Dibekali dengan pendekatan yang holistik dan komitmen antropologi akan pemahaman tentang manusia.

Intenarnalisasi diterapkan melalui kurikulum dalam manajemen pendidikan. Materi sesuaikan dengan letak georafis suatu lembaga pendidikan. Sehingga potensi lokal masing-masing daerah dirangkum dalam proses internalisasi keragaman. Sehingga peserta didik dapat mengenali potensi budayanya sendiri, mengembangkan

${ }^{21}$ Gazalba, Islam dan Perubahan Sosiobudaya. 
budaya, menumbuhkan cinta tanah air. Guru mengajak peserta didik untuk mempelajari sesuatu dalam rangka suatu pelajaran di sekolah.

Internalisasi kesetaraan dalam diversity berguna bagi peserta didik untuk membantu mereka memahami kehidupan nyata dalam lingkungan beserta segala masalahnya. Misalnya, siswa diajak ke museum, kantor, percetakan, bank, pengadilan, atau ke suatu tempat yang mengandung nilai sejarah atau kebudayaan tertentu. Dalam hal ini memberikan ilustrasi bahwa kajian perbedaan di Indonesia telah berhasil dibentuk dalam kebersamaan yang dimulai di lingkungan sekolah. Karena keragaman memiliki hubungan yang erat terhadap kebudayaan. Dalam menguraikan posisi keragaman di masyarakat Indonesia sebagai suatu keniscayaan sebagai negara kepulauan. Keragaman merupakan bagian dari banyak budaya yang di dalamnya terdapat kesetaraan dalam memiliki hak dan kewajiban. Kesetaraan tersebut dalam konsep agama merupaakan bagian dari mengalahkan ego.

Nicholas Berdyaev memandang agama sebagai usaha untuk mengatasi keheningan guna melepaskan ego dari ketertutupannya, untuk mencapai kebersamaan dan keterakhiran. Selain itu, William james memaknakan agama sebagai perasaan, tindakan dan pengalaman masing-masing manusia dalam keheningannya. ${ }^{22}$ Dalam pandangan tersebut merupakan pengakuan terhadap sifat-sifat pada manusia yang memiliki sikap egois. Di balik sikap egois ada kecakapan yang perlu dikembangkan pada peserta didik.

Pengembangan kecakapan hidup terdiri dari: kecakapan personal, kecakapan sosial, kecakapan akademik, dan kecakapan vokasional (keterampilan) untuk bekerja. ${ }^{23}$ Prinsip ini menitikberatkan pada lembaga pendidikan yang mampu berkomunikasi secara aktif dalam kebersamaan yang tertanam sifat saling percaya. Lembaga pendidikan hendaknya mempunyai program yang cukup lentur dan beradaptasi secara terus menerus dengan perubahan-perubahan layanan lembaga lain di masyarakat.

Perkembangan keragaman merupakan bagian dari pengetahuan, tekhnologi, yang begitu cepat perlu diikuti dengan program yang relevan. Relevansi. Peran dan fungsi lembaga pendidikan ditentukan sesuai dengan kondisi masyarakat yang menjadi

\footnotetext{
${ }^{22}$ Robert W. Crapps, 'Dialog Psikologi dan Agama Sejak William James Hingga Gordon W', Allport, Yogyakarta: Penerbit Kanisius, 1993.

${ }^{23}$ Nasution et al., Tradisi Baru Penelitian Agama Islam.
} 
latar belakang peserta didik. Karena anak setelah menyelesaikan studi akan kembali ke masyarakat sebagai pengguna lulusan suatu lembaga pendidikan.

Lembaga pendidikan secara terbuka bersedia untuk diobservasi oleh masyarakat. Masyarakat dapat melihat secara langsung proses dan sarana di lembaga pendidikan. Agar masyarakat mengetahui apa dan bagaimana penyelenggaraan pendidikan di lembaga tersebut. Pemberian kesempatan kepada masyarakat. Masyarakat dapat dengan suka rela membantu kegiatan di lembaga Pendidikan.

Lembaga pendidikan bersama masyarakat hendaknya mengembangkan program kegiatan dan layanan guna memperluas, memperbaharui, memadukan peng-alaman berbagai kelompok umur pada semua tingkatan. Lembaga harus memperhatikan kebutuhan masyarakat ini. Dalam melaksanakan kerjasama dan meningkatkan keterlibatan masyarakat dengan lembaga pendidikan sering muncul beberapa kendala seperti kurangnya jalinan komunikasi dan kemungkinan usaha masyarakat mengeksploitasi keberadaaan lembaga pendidikan, kegiatan mengkritik dan menyerang yang bertujuan menjatuhkan kebijakan lembaga pendidikan. Misalnya suatu perusahaan bersedia menjadi donatur penyelenggaraan suatu lembaga pendidikan dengan syarat agar siswa mau menggunakan produk tertentu. Untuk mengatasi kendala tersebut maka pihak Lembaga pendidikan perlu tanggap dengan cara menganalisis motif diballik pemberian dana tersebut. Pimpinan perlu menganalisis dan memecahkan masalah secara bijaksana.

Secara khusus Azra ${ }^{24}$ menyebutkan, di kalangan masyarakat Muslim Indonesia, partisipasi masyarakat dalam rangka pendidikan pendekatan antrolopogi, agama, dan sosial, yaitu suatu sejarah perkembangan Islam di bumi Nusantara. Hampir seluruh lembaga pendidikan Islam di Indonesia, mulai dari rangkang, dayah, meunasah (Aceh), surau (Minangkabau), pesantren (Jawa), bustanul atfal, diniyah dan sekolah-sekolah Islam lainnya didirikan dan dikembangkan oleh masyarakat Muslim.

\section{Penutup}

Interaksi diversity danKesetaraan pada peserta didk dalam lembaga pendidikan Islam. Keseragaman pada setiap peserta didik hanya dapat dicapai melalui organisasi,

${ }^{24}$ Azyumardi Azra, 'Jaringan Global Dan Lokal Islam Nusantara', Bandung: Mizan, 2002. 
terutama organisasi pendidikan yang dikelola secara baik. Mempelajari kebutuhan peserta didik dalam melihat apa yang bisa diperbuat lembaga pendidikan untuk memenuhi kebutuhan masyarakat, yang akhirnya dapat melayani kebutuhan mereka. Pada saat yang tepat pihak sekolah malibatkan masyarakat sekitar untuk berpartisipasi dalam kegiatan sekolah untuk menimbulkan sikap trust antar lembaga pendidikan dan warga sekitar.

Internalisasi kesertaraan dalam diversitypada hakikatnya memiliki sistem nilainilaimora agama dalam sosial-budaya yang kemudian dapat ditransformasikan dalam berbagai kehidupan di masyarakat termasuk dalam sistem lembaga pendidikan Islam. Diversity ternyata sangat berdampak signifikan bahkan merupakan keniscayaan untuk tidak terjebak dalam pandangan tentang keragaman praktis. Keragaman berkaitan dengan perbedaan sifat dan kondisi masing-masing komponen sistem kesertaraan. Pemahaman demikian dapa menyadarkan bahwa dalam sebuah kebudayaan. 


\section{Daftar Pustaka}

Asad, Talal. 'Anthropological Conceptions of Religion: Reflections on Geertz'. Man, 1983.

Azra, Azyumardi.'Jaringan Global dan Lokal Islam Nusantara'. Bandung: Mizan, 2002.

Bakhtiar, Amsal. Filsafat Agama: Wisata Pemikiran Dan Kepercayaan Manusia. Raja Grafindo Persada, 2007.

Crapps, Robert W. 'Dialog Psikologi dan Agama Sejak William James Hingga Gordon W'. Allport, Yogyakarta: Penerbit Kanisius, 1993.

Diantoro, Fery. 'Manajemen Peserta Didik Dalam Pembinaan Perilaku Keberagamaan'. Cendekia: Jurnal Kependidikan dan Kemasyarakatan 16, no. 2 (22 November 2018): 409-26. https://doi.org/10.21154/cendekia.v16i2.1207.

Fauzi, Ahmad. 'Manajemen Pendidikan Islam Di Pesantren; Berbasis Kearifan Lokal Kajian Fenomenologis'. In Seminar Nasional Pendidikan, Fakultas Ilmu Pendidikan Universitas Negeri Malang Sinergitas Keluarga, Sekolah Dan Masyarakat Dalam Penguatan Pendidikan Karakter, 51-62, 2017.

Gazalba, Sidi. Islam Dan Perubahan Sosiobudaya: Kajian Islam Tentang Perubahan Masyarakat. Pustaka Antara, 1983.

Huda, M. Dimyati. 'Pendekatan Antropologis Dalam Studi Islam'. Didaktika Religia 4, no. 2 2016.

Koentjaraningrat. Pengantar Ilmu Antropologi. Penerbit Pt Rineka Cipta, 1990.

Misbah, M. 'Reorientasi Jurusan Manajemen Pendidikan Islam (MPI) Antara Tenaga Kependidikan Dan Tenaga Pendidik'. Cendekia: Jurnal Kependidikan Dan Kemasyarakatan 16, no. 1 (30 July 2018): 83-101. https://doi.org/10.21154/cendekia.v16i1.1178.

Nasution, Harun. Islam Ditinjau Dari Berbagai Aspeknya. Penerbit Universitas Indonesia, 1985.

Nasution, Harun, Jujun S. Suriasumantri, Johan H. Meuleman, Mastuhu, and M. Deden Ridwan. Tradisi Baru Penelitian Agama Islam: Tinjauan Antardisiplin Ilmu. Diterbitkan atas kerja sama Pusjarlit dengan Nuansa, 1998.

Purwanto, Iwan. 'Manajemen Strategi'. Bandung: Yrama Widya, 2008.

Shomad, Abd. 'Selayang Pandang Tentang Antropologi Pendidikan Islam'. Jurnal Pendidikan Agama Islam 1, no. 1 (2004).

Steenbrink, Karel A. Pesantren, Madrasah, Sekolah: Pendidikan Islam Dalam Kurun Moderen. Lembaga Penelitian, Pendidikan dan Penerangan Ekonomi dan Sosial, 1986.

Suparlan, Parsudi. 'Pendidikan Agama Islam: Tinjauan Disiplin Antropologi'. Bandung: Nuansa, 2001.

Tobroni, Tobroni, and Asyraf Isyraqi. 'The Role Of Islamic Religion Education For Social Etic Of Frienship and Peace Formation Case Indonesia and Malaysia', 2012.

Winarsih, Sri. 'Kebijakan dan Implementasi Manajemen Pendidikan Tinggi dalam Meningkatkan Mutu Pendidikan'. Cendekia: Jurnal Kependidikan Dan 
Kemasyarakatan 15, no. 2 (24 June 2017): 51-66. https://doi.org/10.21154/cendekia.v15i2.1005.

Yazdi, Mehdi Ha'iri, and Ilmu Hudhuri. 'Prinsip-Prinsip Epistemologi Dalam Filsafat Islam, Ter'. Ahsin Mohammad (Andung: Mizan, 1996), 1994. 